\title{
Badanie stabilności barwnych znaczników fluorescencyjnych w silnie zasiarczonych wodach złożowych
}

\section{Study on the stability of colored fluorescent tracers in highly sulfated reservoir waters}

\author{
Katarzyna Wojtowicz \\ Instytut Nafty i Gazu - Państwowy Instytut Badawczy
}

\begin{abstract}
STRESZCZENIE: W artykule zostały przedstawione zagadnienia związane z oznaczaniem barwnych znaczników fluorescencyjnych, takich jak fluoresceina, eozyna żółtawa, rodamina B i uranina, w wodach złożowych metodą spektrofotometryczną. W tym celu sprawdzono wpływ pH roztworu na widma absorpcji badanych znaczników. Otrzymane wyniki wykazały, że fluoresceina, rodamina B i uranina są wrażliwe na zmianę odczynu roztworu, dlatego w dalszych badaniach wskazane jest stosowanie stabilnych roztworów znaczników oraz kontrola i ewentualna korekta $\mathrm{pH}$. W ramach badań wykreślono krzywe kalibracyjne fluoresceiny, eozyny żółtawej, rodaminy B i uraniny w wodzie destylowanej, wodzie złożowej A4 i silnie zasiarczonych wodach złożowych A5 i A6 oraz przeprowadzono walidację metody analitycznej. Walidacja ta obejmowała wyznaczenie liniowości, odchylenia standardowego i względnego odchylenia standardowego badanych znaczników. Wysokie wartości współczynników regresji $(0,9927-0,9998)$ analizowanych znaczników świadczą o dobrym dopasowaniu liniowym, natomiast niskie wartości odchylenia standardowego i względnego odchylenia standardowego - o powtarzalności i precyzji metody. Szczególną uwagę zwrócono na badania trwałości barwnych znaczników fluorescencyjnych w silnie zasiarczonych wodach złożowych. W tym celu sporządzono roztwory badanych znaczników o stężeniu $10 \mathrm{mg} / \mathrm{dm}^{3} \mathrm{w}$ wodzie destylowanej, wodzie złożowej A4 i silnie zasiarczonych wodach złożowych A5 i A6. Pomiar stężenia znaczników w badanych wodach wykonywano co 2 dni przez okres 1 miesiąca. Uzyskane wyniki badań wykazały, że roztwory fluoresceiny, eozyny żółtawej, rodaminy B i uraniny są stabilne w wodzie destylowanej i wodzie złożowej A4, natomiast w wodach złożowych A5 i A6 ulegają degradacji. Najbardziej wrażliwe okazały się fluoresceina i jej pochodna uranina, które w wodzie złożowej A6 uległy całkowitej degradacji po 20 (fluoresceina) i 22 (uranina) dniach. Nieznacznie bardziej trwałe w silnie zasiarczonych wodach złożowych okazały się eozyna żółtawa i rodamina B, które w wodzie złożowej A6 uległy całkowitej degradacji po 24 dniach.
\end{abstract}

Słowa kluczowe: znacznik, fluoresceina, eozyna Y, rodamina B, uranina

\begin{abstract}
The article presents the issues related to the determination of colored fluorescent tracers such as fluorescein, eosin yellowish, rhodamine B and uranine in reservoir waters by spectrophotometric method. For this purpose, the influence of the $\mathrm{pH}$ of the solution on the absorption spectra of the tested tracers was checked. Test results show that fluorescein, rhodamine B and uranine are sensitive to changes in the buffer $\mathrm{pH}$, therefore it is advisable to use stable tracer solutions as well as to control and possibly correct $\mathrm{pH}$ in further tests. As part of the study, calibration curves of fluorescein, eosin yellowish, rhodamine B and uranine in distilled water, reservoir water A4 and highly sulfated reservoir waters A5 and A6 were plotted and the analytical methods were validated. Analytical validation included determination of linearity, standard deviation and relative standard deviation of the tested tracers solutions. High values of the regression parameters (0.9927-0.9998) of the analyzed tracers prove a good linear fit, while low values of standard deviation and relative standard deviation prove its repeatability and precision. Particular attention was paid to testing the stability of colored fluorescent tracers in highly sulfated reservoir waters. For this purpose, solutions of the tested tracers were prepared at concentrations of $10 \mathrm{mg} / \mathrm{dm}^{3}$ in distilled water, A4 reservoir water and highly sulfated A5 and A6 reservoir waters. Measurements of the tested tracers in the prepared solutions were performed every 2 days over the period of 1 month. The test results show that fluorescein, eosin yellowish, rhodamine B and uranine solutions are stable in the distilled water and A4 reservoir water, while they degrade in the A5 and A6 reservoir waters. Fluorescein and uranine turned out to be the most sensitive, as they degraded completely in the A6 reservoir water after 20 (fluorescein) and 22 (uranine) days. Yellowish eosin and rhodamine B turned out to be slightly more stable in highly sulfated reservoir waters, as they degraded completely in the A6 reservoir water after 24 days.
\end{abstract}

Key words: tracer, fluorescein, eosin yellowish, rhodamine B, uranine.

Autor do korespondencji: K. Wojtowicz, e-mail: katarzyna.wojtowiczk@inig.pl

Artykuł nadesłano do Redakcji: 18.11.2020 r. Zatwierdzono do druku: 29.01.2021 r. 


\section{Wstęp}

Metody znacznikowe stanowią ważne narzędzie diagnostyczne w przemyśle naftowym i gazowniczym, pozwalające na monitorowanie dróg migracji płynów złożowych. Terminem znaczniki (ang. tracers) określa się substancje chemiczne (proste lub złożone) lub specjalnie oznaczone cząstki badanego materiału, które można łatwo wykrywać (śledzić) w celu badania procesów chemicznych, fizycznych lub biologicznych zachodzących w różnych układach (Jaworski, 2005; Kania i Matyasik, 2013).

W literaturze dostępnych jest kilka metod klasyfikacji substancji znacznikowych. Powszechnie stosuje się podział znaczników na dwie podstawowe grupy: naturalne (ang. natural tracers) i sztuczne (ang. artificial tracers) (Chrysikopoulos, 1993). Zgodnie z definicją znaczniki naturalne to substancje występujące w danym środowisku, natomiast znaczniki sztuczne to substancje wyprodukowane przez człowieka i wprowadzone przez niego do badanego środowiska. W literaturze można spotkać się również z pojęciem znaczników środowiskowych (ang. environmental tracers), do których należą zarówno znaczniki naturalne, jak i znaczniki powstałe w wyniku działalności człowieka. Znaczniki środowiskowe są łatwo wprowadzane do środowiska i uczestniczą w naturalnym obiegu wody w przyrodzie (Doveri i Mussi, 2014; Elliot, 2014; Yeh et al., 2014). Zarówno znaczniki naturalne, jak i sztuczne dzieli się na dwie kategorie: pasywne (ang. passive tracers) i aktywne (ang. partitioning tracers). Różnice pomiędzy znacznikami pasywnymi a aktywnymi wynikają z ich natury chemicznej i ich właściwości fizyczno-chemicznych. Znaczniki pasywne charakteryzują się takimi samymi właściwościami fizyczno-chemicznymi jak płyn, do którego są dodawane (woda złożowa), nie ulegają reakcjom chemicznym z badanym płynem, wymianie jonowej oraz sorpcji na skale lub innych fazach złożowych (ropa naftowa). W warunkach rzeczywistych spełnienie wszystkich kryteriów charakteryzujących znaczniki pasywne jest praktycznie niemożliwe. Dlatego znaczniki pasywne są użyteczne jedynie w pracach laboratoryjnych lub w rozważaniach teoretycznych mających na celu poszukiwanie nowych znaczników. W rzeczywistości zazwyczaj mamy do czynienia ze znacznikami aktywnymi, które w mniejszym lub większym stopniu mogą ulegać różnego rodzaju interakcjom (sorpcja, zjawisko podziału, wymiana jonowa, reakcja chemiczna) ze skałą lub płynami złożowymi. Dlatego określenie ścieżki przepływu wody złożowej w złożu, jak również szybkości przepływu może stanowić poważne wyzwanie w warunkach rzeczywistych (Guan i Du, 2004; Shook et al., 2009; Asadi i Shook, 2010; Huseby et al., 2010; Cao et al., 2020).
W literaturze równie często spotykany jest podział znaczników na radioaktywne i chemiczne (Zemel, 1995; Such, 2010). Znaczniki chemiczne stanowią najliczniejszą i najszerzej wykorzystywaną grupę znaczników w przemyśle nafty i gazu. Wyróżnia się trzy typy znaczników chemicznych: alkohole, sole oraz barwne znaczniki fluorescencyjne. Ogólny podział znaczników stosowanych w przemyśle nafty i gazu przedstawiono na diagramie (rys. 1).

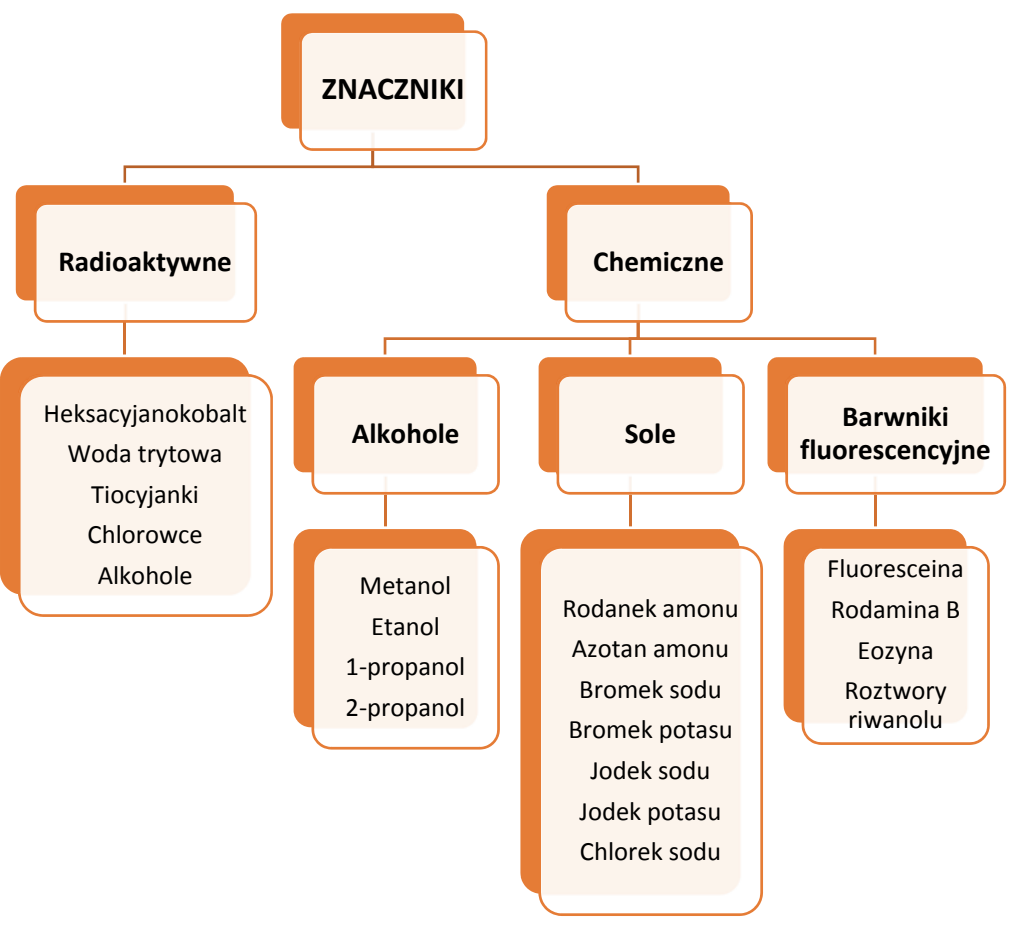

Rys. 1. Ogólny podział znaczników w przemyśle naftowym (Such, 2010)

Fig. 1. General classification of tracers in oil industry (Such, 2010)

Znaczniki w przemyśle nafty i gazu zaczęto wykorzystywać w latach 60. XX wieku, kiedy przeprowadzono pierwsze testy międzyotworowe z użyciem substancji znacznikowych z powodzeniem stosowanych w hydrologii. Największy rozwój metod znacznikowych nastapił jednak w latach 90. XX wieku wraz z silnym postępem przemysłu chemicznego (Zemel, 1995; Serres-Piole et al., 2012). W tamtym okresie znaczniki zaczęto wykorzystywać w badaniach obecności śladów wody w złożu oraz do monitorowania migracji wód w złożach. Obecnie metody znacznikowe stanowią niezastąpione narzędzie diagnostyczne stosowane w przemyśle naftowym i gazowniczym (Serres-Piole et al., 2012). Pomimo niskich kosztów procesu oraz małej pracochłonności metody znacznikowe pozwalają na:

- zobrazowanie ścieżek przepływu płynów w złożu;

- określenie kierunków i prędkości przepływu mediów złożowych w złożu;

- ujawnienie połączeń między odwiertami (planowanych oraz nieoczekiwanych); 
- ustalenie rozkładu szczelin, uskoków i nieciągłości w złożu;

- stwierdzenie udziału ropy, gazu i wody w złożu;

- oszacowanie resztkowego nasycenia złoża ropą naftową.

\section{Metodyka badawcza}

Istota badania spektrofotometrycznego oparta jest na pomiarze absorpcji promieniowania przechodzącego przez badaną próbkę. Na skutek oddziaływania z analitem natężenie promieniowania przechodzącego przez próbkę ulega zmianie, malejąc wykładniczo. Zgodnie z prawem Lamberta-Beera zmiana natężenia promieniowania zależy od długości drogi optycznej, a intensywność promieniowania - od stężenia analitu. Dane zależności opisuje równanie (1) (Mäntele i Deniz, 2017):

$$
A=\log \frac{I_{0}}{I_{t}} \cdot \varepsilon \cdot c \cdot l
$$

gdzie:

$A$ - absorbancja,

$I_{0}$ - natężenie promieniowania padającego na próbkę,

$I_{t}$ - natężenie promieniowania przepuszczonego przez próbkę,

$\varepsilon-$ molowy współczynnik absorpcji,

$c$ - stężenie związku analizowanego w próbce,

$l$-długość drogi optycznej.

Promieniowanie po przejściu przez analizowaną próbkę kierowane jest na detektor, gdzie zachodzi zmiana impulsów świetlnych na sygnał elektryczny. Impuls elektryczny trafia do komputera, gdzie obliczana jest absorbancja dla określonej długości fali promieniowania. Następnie za pomocą

Tabela 1. Właściwości fizyczno-chemiczne badanych znaczników fluorescencyjnych

Table 1. Physical and chemical properties of tested fluorescent tracers

\begin{tabular}{|c|c|c|c|c|}
\hline $\begin{array}{c}\text { Właściwość } \\
\text { fizyczno-chemiczna }\end{array}$ & Fluoresceina & Eozyna Y & Rodamina B & Uranina \\
\hline Wzór sumaryczny & $\mathrm{C}_{20} \mathrm{H}_{12} \mathrm{O}_{5}$ & $\mathrm{C}_{20} \mathrm{H}_{6} \mathrm{Br}_{4} \mathrm{Na}_{2} \mathrm{O}_{5}$ & $\mathrm{C}_{28} \mathrm{H}_{31} \mathrm{~N}_{2} \mathrm{O}_{3} \mathrm{Cl}$ & $\mathrm{C}_{20} \mathrm{H}_{10} \mathrm{Na}_{2} \mathrm{O}_{5}$ \\
\hline \multicolumn{5}{|l|}{ Wzór strukturalny } \\
\hline Masa cząsteczkowa [g/mol] & 332,31 & 691,86 & 479,02 & 376,28 \\
\hline Postać i wygląd & $\begin{array}{c}\text { pomarańczowoczerwony } \\
\text { proszek }\end{array}$ & $\begin{array}{l}\text { pomarańczowy, czerwo- } \\
\text { ny lub czerwonobrązowy } \\
\text { proszek }\end{array}$ & $\begin{array}{l}\text { czerwonofioletowy lub } \\
\text { ciemnozielony proszek }\end{array}$ & $\begin{array}{c}\text { pomarańczowoczerwony } \\
\text { proszek }\end{array}$ \\
\hline Temperatura wrzenia $\left[{ }^{\circ} \mathrm{C}\right]$ & 620,8 & brak danych & brak danych & brak danych \\
\hline Temperatura topnienia $\left[{ }^{\circ} \mathrm{C}\right]$ & $314-316$ & $295-296$ & $210-211$ & $<360$ \\
\hline Gęstość $\left(20^{\circ} \mathrm{C}\right)\left[\mathrm{g} / \mathrm{cm}^{3}\right]$ & 1,602 & 1,018 & 1,31 & brak danych \\
\hline $\mathrm{pKa}[-]$ & $\begin{array}{c}2,08 \\
4,31 \\
6,43 \\
\text { (Nishikiori et al., 2019) }\end{array}$ & $\begin{array}{c}2,02 \\
3,8 \\
\text { (Nishikiori et al., 2019) }\end{array}$ & $\begin{array}{c}3,7 \\
\text { (Wang et al., 2014) }\end{array}$ & $\begin{array}{c}2,27 \\
4,32 \\
6,5 \\
\text { (Gerke et al., 2013) }\end{array}$ \\
\hline $\begin{array}{l}\text { Rozpuszczalność w wodzie } \\
\left(20^{\circ} \mathrm{C}\right)\left[\mathrm{g} / \mathrm{dm}^{3}\right]\end{array}$ & 0,3 & 300 & 34 & 500 \\
\hline $\begin{array}{l}\text { Rozpuszczalność w etanolu } \\
\left(20^{\circ} \mathrm{C}\right)\left[\mathrm{g} / \mathrm{dm}^{3}\right]\end{array}$ & 20 & 10 & 15 & 140 \\
\hline $\begin{array}{l}\text { Maksimum absorpcji [nm] } \\
\text { (pH zasadowe) }\end{array}$ & $490 \pm 5$ & $516 \pm 5$ & $554 \pm 5$ & $491 \pm 5$ \\
\hline $\begin{array}{l}\text { Maksimum emisji [nm] } \\
\text { (pH zasadowe) }\end{array}$ & $520 \pm 5$ & $538 \pm 5$ & $576 \pm 5$ & $512 \pm 5$ \\
\hline Szczególne zagrożenia & substancja palna & związek rakotwórczy & substancja palna & substancja palna \\
\hline Odniesienie literaturowe & $\begin{array}{c}\text { Käss W., 1998; } \\
\text { Hardy et al., 2016; } \\
\text { National Center for Bio- } \\
\text { technology Information, } \\
\text { 2020b }\end{array}$ & $\begin{array}{c}\text { Käss W., 1998; } \\
\text { Hardy et al., 2016; } \\
\text { National Center for Bio- } \\
\text { technology Information, } \\
\text { 2020a }\end{array}$ & $\begin{array}{c}\text { Käss W., 1998; } \\
\text { Hardy et al., 2016; } \\
\text { National Center for Bio- } \\
\text { technology Information, } \\
\text { 2020c }\end{array}$ & $\begin{array}{l}\text { Käss W., 1998; } \\
\text { Hardy et al., 2016; } \\
\text { National Center for Bio- } \\
\text { technology Information, } \\
\text { 2020d }\end{array}$ \\
\hline
\end{tabular}




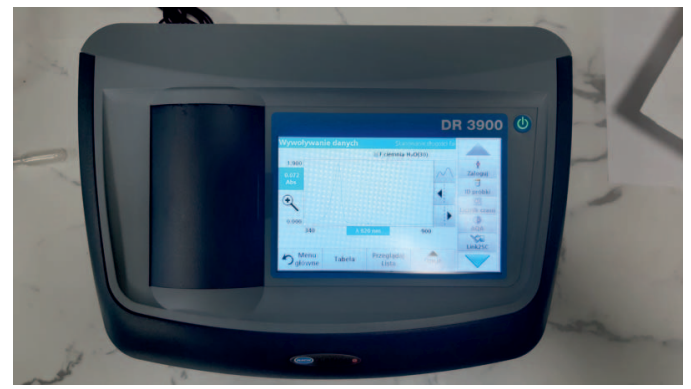

Rys. 2. Spektrofotometr Hach Lange DR 3900

Fig. 2. Spectrophotmeter Hach Lange 3900

krzywych wzorcowych obliczana jest ilość analitu w badanej próbce (Mäntele i Deniz, 2017).

W Zakładzie Technologii Eksploatacji Płynów Złożowych INiG - PIB analizy barwnych znaczników fluorescencyjnych wykonuje się metodą spektrofotometryczną na wysokowydajnym spektrofotometrze DR 3900 firmy Hach Lange w zakresie światła widzialnego od $340 \mathrm{~nm}$ do $900 \mathrm{~nm}$ (rys. 2).

\section{Charakterystyka materiału badawczego}

W badaniach trwałości barwnych znaczników fluorescencyjnych w silnie zasiarczonych wodach złożowych przetestowano cztery barwne znaczniki fluorescencyjne: fluoresceinę $(\mathrm{POCH}$, nr kat. 427770118), uraninę (Trotec, nr kat. 208-253-0), rodaminę B (POCH, nr kat. 764140114) oraz eozynę żółtawą (eozyna Y) (Chempur, nr kat. 243768301). Wytypowane znaczniki mają zdolność selektywnej absorpcji światła o określonej długości fali, co pozwala na oznaczanie ich w wodach z wykorzystaniem szybkich i prostych metod spektrofotometrycznych. Właściwości fizyczno-chemiczne badanych znaczników fluorescencyjnych przedstawiono w tabeli 1 .

Dla każdego z badanych znaczników sporządzono roztwory w wodzie destylowanej, wodzie złożowej A4 i dwóch silnie zasiarczonych wodach złożowych A5 i A6, pobranych ze złóż ropy naftowej zlokalizowanych w zachodniej Polsce. Skład fizyczno-chemiczny wód złożowych A4, A5 i A6 przedstawiono w tabeli 2 .

\section{Wpływ pH na widma absorpcji znaczników fluorescencyjnych}

Przed przystąpieniem do badań trwałości znaczników fluorescencyjnych w wodach silnie zasiarczonych konieczna była ocena wpływu $\mathrm{pH}$ na widma absorpcji fluoresceiny, eozyny żółtawej, rodaminy B i uraniny. Odczyn rzeczywistych wód

Tabela 2. Skład fizyczno-chemiczny wód złożowych wykorzystanych w badaniach trwałości znaczników

Table 2. Physical and chemical composition of reservoir waters used in testing the stability of tracers

\begin{tabular}{|c|c|c|c|c|}
\hline Oznaczenia & Jednostka & Woda zlożowa A4 & Woda zlożowa A5 & Woda złożowa A6 \\
\hline $\mathrm{pH}$ & - & 5,4 & 5,5 & 5,9 \\
\hline Eh & $\mathrm{mV}$ & -341 & -497 & -518 \\
\hline Gęstość $\left(20^{\circ} \mathrm{C}\right)$ & $\mathrm{g} / \mathrm{cm}^{3}$ & 1,179 & 1,196 & 1,002 \\
\hline Sucha pozostałość $\left(105^{\circ} \mathrm{C}\right)$ & \multirow{19}{*}{$\mathrm{mg} / \mathrm{dm}^{3}$} & 291142 & 331344 & 9112 \\
\hline Sucha pozostałość $\left(180^{\circ} \mathrm{C}\right)$ & & 286596 & 302932 & 8822 \\
\hline Substancje nierozpuszczone & & 153 & 494 & 2,0 \\
\hline Pozostałość po prażeniu w $600^{\circ} \mathrm{C}$ & & 266125 & 200100 & 6818 \\
\hline Zawartość chlorków $\mathrm{Cl}^{-}$ & & 163070 & 180795 & 4963 \\
\hline Zawartość siarczanów $\mathrm{SO}_{4}^{2-}$ & & 87 & 22,1 & 13,0 \\
\hline Zawartość siarczków $\mathrm{S}^{2-}$ & & n.s. & 708,0 & 741,0 \\
\hline Zawartość węglanów $\mathrm{CO}_{3}{ }^{2-}$ & & n.s. & n.s. & n.s. \\
\hline Zawartość wodorowęglanów $\mathrm{HCO}_{3}^{-}$ & & 866 & 573 & 695 \\
\hline Zawartość wapnia $\mathrm{Ca}^{2+}$ & & 15230 & 21042 & 260,5 \\
\hline Zawartość magnezu $\mathrm{Mg}^{2+}$ & & 7050 & 2431 & 48,6 \\
\hline Zawartość żelaza $\mathrm{Fe}_{\text {og. }}$ & & 0,43 & 0,60 & 0,04 \\
\hline Zawartość manganu $\mathrm{Mn}^{2+}$ & & 0,12 & $<0,1$ & $<0,1$ \\
\hline Zawartość miedzi $\mathrm{Cu}$ & & 0,064 & 0,3 & 0,2 \\
\hline Zawartość ołowiu Pb & & 1,85 & 0,2 & $<0,1$ \\
\hline Zawartość cynku Zn & & 8,54 & 0,3 & $<0,1$ \\
\hline Zawartość niklu Ni & & 1,29 & $<0,1$ & $<0,1$ \\
\hline Zawartość kobaltu Co & & $<0,1$ & $<0,1$ & $<0,1$ \\
\hline Zawartość kadmu Cd & & $<0,1$ & $<0,1$ & $<0,1$ \\
\hline
\end{tabular}

n.s. - nie stwierdzono 
złożowych może być różny i w trakcie trwania testu może ulegać zmianie, co jest wynikiem obecności w złożu substancji utleniających. W celu zbadania wpływu pH roztworu na widma absorpcji barwnych znaczników fluorescencyjnych sporządzono serię roztworów fluoresceiny, eozyny żółtawej, rodaminy B oraz uraniny o stężeniu $10 \mathrm{mg} / \mathrm{dm}^{3}$ w roztworach buforowych o znanych wartościach $\mathrm{pH}$ wynoszących $2 ; 4 ; 5,5 ; 7$; 10 i 12 . Widma absorpcji badanych znaczników fluorescencyjnych zamieszczono na rysunkach 3-6.

Jak powszechnie wiadomo, znaczniki fluorescencyjne moga występować w roztworze w różnych formach tautomerycznych: kationowej, neutralnej, anionowej lub dianionu. Wykazano, że fluoresceina oraz jej pochodna uranina mogą przybierać w roztworze siedem form tautomerycznych: kationową $\left(\mathrm{FH}_{3}^{+}\right)$, trzy formy neutralne $(\mathrm{L}, \mathrm{Z}, \mathrm{CH})$, dwie formy anionowe $\left(\mathrm{KF}^{-}, \mathrm{FF}^{-}\right)$ oraz formę dianionu $\left(\mathrm{F}^{2-}\right)$. Konsekwencją występowania wyżej wymienionych form tautomerycznych fluoresceiny i uraniny w roztworze jest silna zależność barwy oraz fluorescencji ich roztworów (a tym samym udziału poszczególnych jej form tautomerycznych $\mathrm{w}$ roztworze) od $\mathrm{pH}$. Udowodniono,

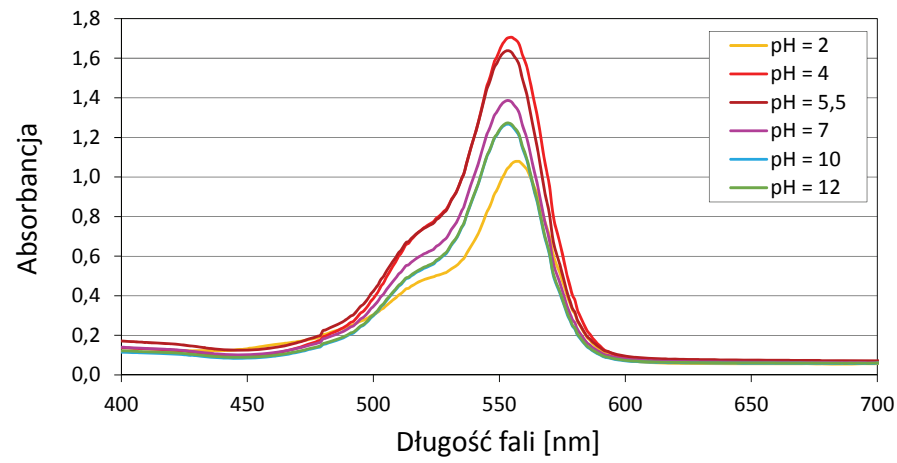

Rys. 3. Zależność widma absorpcji fluoresceiny od pH roztworu (stężenie fluoresceiny w roztworze: $10 \mathrm{mg} / \mathrm{dm}^{3}$ )

Fig. 3. The dependence of the absorption spectrum of fluorescein on the $\mathrm{pH}$ of a solution $\left(10 \mathrm{mg} / \mathrm{dm}^{3}\right.$ concentration of fluorescein in the solution)

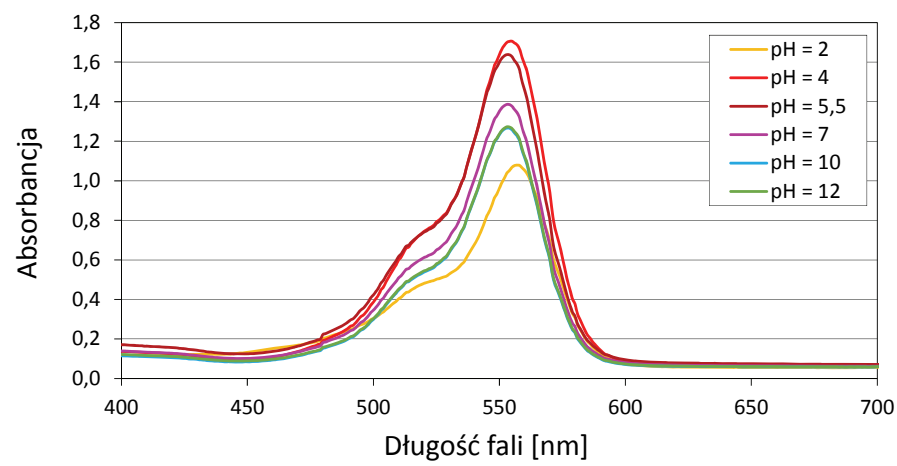

Rys. 5. Zależność widma absorpcji rodaminy B od pH roztworu (stężenie rodaminy B w roztworze: $10 \mathrm{mg} / \mathrm{dm}^{3}$ )

Fig. 5. The dependence of the absorption spectrum of rhodamine $B$ on the $\mathrm{pH}$ of a solution $\left(10 \mathrm{mg} / \mathrm{dm}^{3}\right.$ concentration of rhodamine $\mathrm{B}$ in the solution) że roztwory fluoresceiny w środowisku kwaśnym przybierają barwę żółtą (dominacja formy kationowej $\mathrm{FH}_{3}^{+}$), natomiast w środowisku zasadowym - zieloną (dominacja formy dianionu $\mathrm{F}^{2-}$ ) (Jang et al., 2001; Niazi et al., 2008). Z kolei rodamina $\mathrm{B}$ w roztworze może przybierać trzy formy tautomeryczne: kationową oraz dwie formy neutralne (jon obojnaczy (zwitterjon) - Z, lakton - L). Postać jonu obojnaczego rodaminy $\mathrm{B}(\mathrm{Z})$ dominuje $\mathrm{w}$ równowadze $\mathrm{w}$ rozpuszczalnikach protycznych $\mathrm{z}$ formą laktonu (L), natomiast forma kationu występuje w roztworach kwaśnych (Yamashita et al., 1998; Birtalan et al., 2011).

Z przeprowadzonych badań wynika, że najbardziej wrażliwe na zmiany odczynu roztworu są fluoresceina i jej pochodna uranina. Maksima absorpcji fluoresceiny i uraniny w roztworze o $\mathrm{pH}=2$ obserwowane są przy długości fali $\lambda=437 \mathrm{~nm}$ i wraz ze wzrostem $\mathrm{pH}$ roztworu ulegają przesunięciu w kierunku większych długości fali. Maksimum absorpcji fluoresceiny i jej pochodnej w roztworach zasadowych obserwowane jest przy długości fali $\lambda=490 \mathrm{~nm}$ (Naurath at al., 2011; Weidner et al., 2011). Ponadto w przypadku fluoresceiny i uraniny

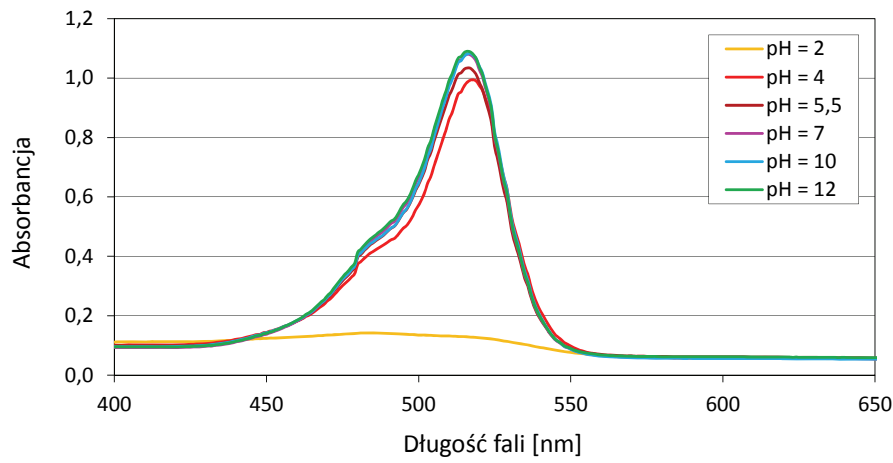

Rys. 4. Zależność widma absorpcji eozyny od pH roztworu (stężenie eozyny w roztworze: $10 \mathrm{mg} / \mathrm{dm}^{3}$ )

Fig. 4. The dependence of the absorption spectrum of eosin yellowish on the $\mathrm{pH}$ of a solution $\left(10 \mathrm{mg} / \mathrm{dm}^{3}\right.$ concentration eosin yellowish in the solution)

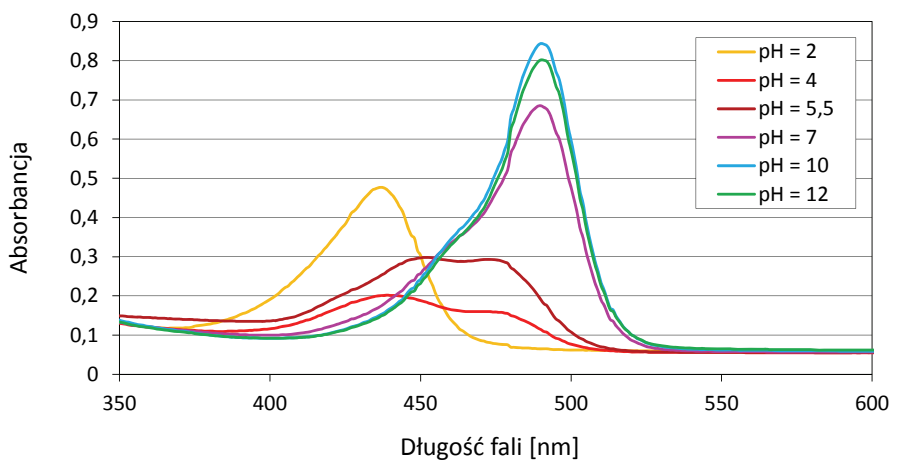

Rys. 6. Zależność widma absorpcji uraniny od pH roztworu (stężenie uraniny w roztworze: $10 \mathrm{mg} / \mathrm{dm}^{3}$ )

Fig. 6. The dependence of the absorption spectrum of uranine on the $\mathrm{pH}$ of a solution $\left(10 \mathrm{mg} / \mathrm{dm}^{3}\right.$ concentration of uranine in the solution) 
obserwuje się zmianę barwy znacznika wraz ze zmianą $\mathrm{pH}$ roztworu z żółtej (odczyn kwaśny) na zieloną (odczyn zasadowy). W przypadku fluoresceiny i uraniny wraz ze wzrostem $\mathrm{pH}$ roztworu wzrasta jego absorbancja i obserwuje się tzw. przesunięcie batochromowe (Doughty, 2010; Slyusareva i Gerasimova, 2014).

Zdecydowanie mniejszy wpływ pH na widma absorpcji stwierdzono w roztworach rodaminy B i eozyny żółtawej. W przypadku tych znaczników fluorescencyjnych nie zaobserwowano zmian przesunięcia maksimum absorpcji i w każdym roztworze występowało ono przy długości fali $\lambda=553 \mathrm{~nm}$ (rodamina B) i $\lambda=516 \mathrm{~nm}$ (eozyna żółtawa). Ponadto dla rodaminy B zaobserwowano wpływ $\mathrm{pH}$ roztworu na intensywność widma absorpcji. Najwyższe wartości absorbancji roztworu rodaminy B zaobserwowano przy pH lekko kwaśnym, równym 4.

Na podstawie przeprowadzonych badań stabilności barwnych znaczników fluorescencyjnych w wodach o różnym $\mathrm{pH}$ stwierdzono, że odczyn roztworu znacząco wpływa na widma absorpcji fluoresceiny i uraniny. Ponadto zaobserwowano nieznaczny wpływ pH roztworu na intensywność widm absorpcji

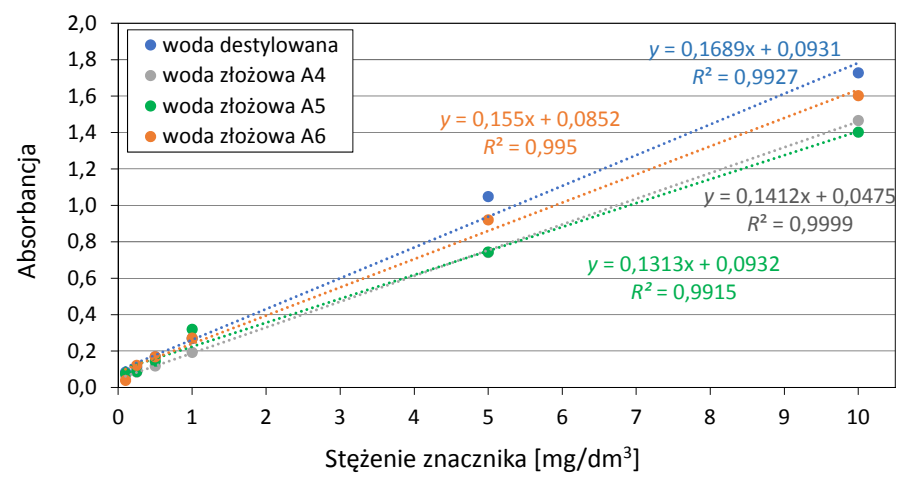

Rys. 7. Zestawienie krzywych kalibracyjnych fluoresceiny w badanych wodach złożowych przy stałym $\mathrm{pH}=7$

Fig. 7. Summary of fluorescein calibration curves in tested reservoir waters at constant $\mathrm{pH}=7$

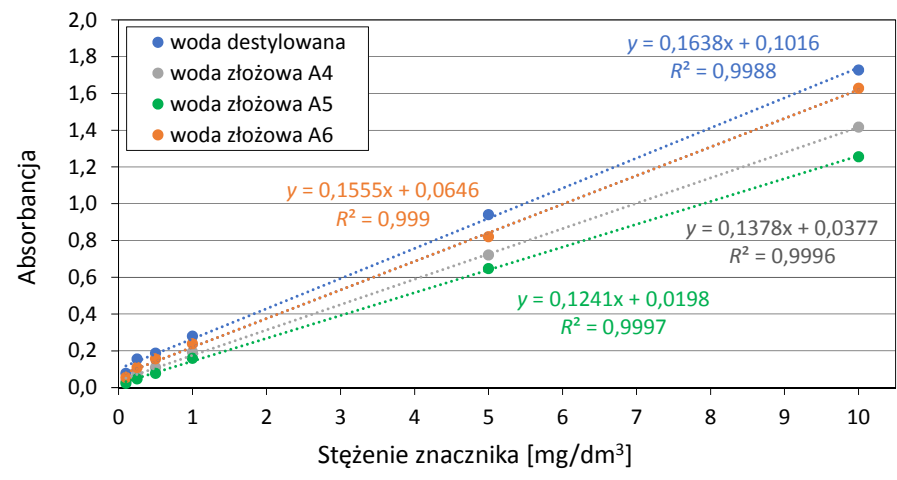

Rys. 9. Zestawienie krzywych kalibracyjnych rodaminy B w badanych wodach złożowych

Fig. 9. Summary of rhodamine B calibration curves in tested reservoir waters rodaminy B. Dlatego w przypadku stosowania barwnych znaczników fluorescencyjnych do badania migracji wód w złożach wskazane jest użycie substancji stabilizujących, np. EDTA, lub buforowanych roztworów znaczników (Buzády et al., 2006). Ponadto w przypadku wód złożowych należy sprawdzić odczyn roztworu przed analizą i w razie konieczności przeprowadzić jego korektę przez dodanie $\mathrm{HCl}$ lub $\mathrm{NaOH}$. Pozwala to na wyeliminowanie błędów jakościowych i ilościowych związanych ze zmianą pH wody złożowej w trakcie testu.

\section{Kalibracja układu i walidacja metody analitycznej}

Kalibracja polega na przedstawieniu zależności sygnału analitycznego od stężenia analitu i wykorzystaniu tej zależności do określenia zawartości analitu w próbce. Do sporządzenia krzywych wzorcowych badanych znaczników fluorescencyjnych przygotowano serię roztworów wzorcowych fluoresceiny, eozyny żółtawej, rodaminy B i uraniny o stężeniach $0,1 \mathrm{mg} / \mathrm{dm}^{3}$, $0,25 \mathrm{mg} / \mathrm{dm}^{3}, 1 \mathrm{mg} / \mathrm{dm}^{3}, 5 \mathrm{mg} / \mathrm{dm}^{3}, 10 \mathrm{mg} / \mathrm{dm}^{3}, 20 \mathrm{mg} / \mathrm{dm}^{3}$ w wodzie destylowanej i wodach złożowych A4, A5 i A6.

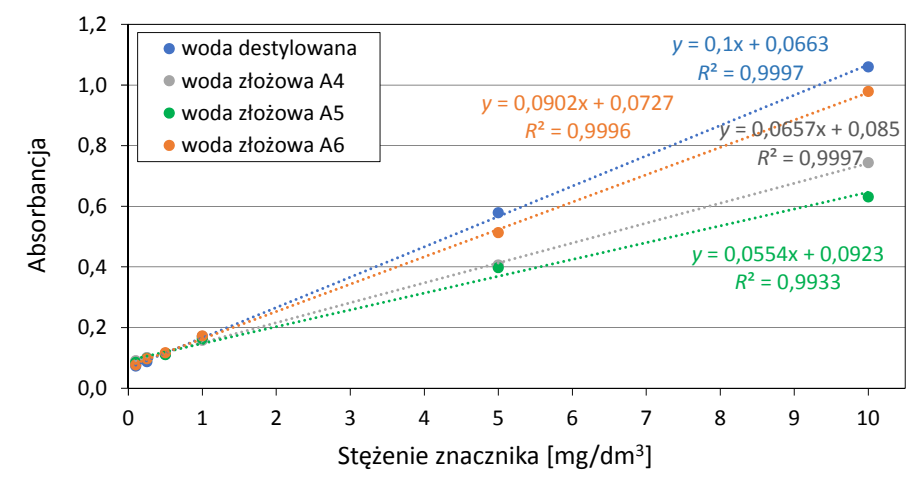

Rys . 8. Zestawienie krzywych kalibracyjnych eozyny żółtawej w badanych wodach złożowych

Fig. 8. Summary of eosin yellowish calibration curves in tested reservoir waters

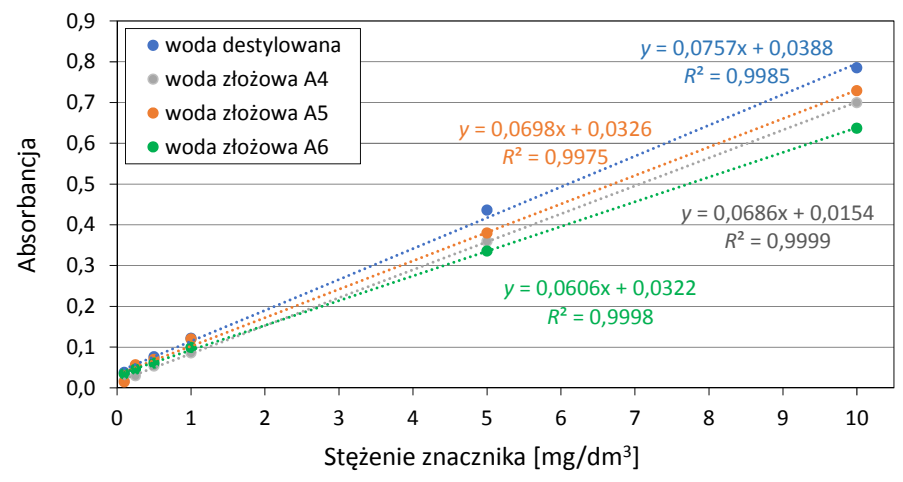

Rys. 10. Zestawienie krzywych kalibracyjnych uraniny w badanych wodach złożowych przy stałym $\mathrm{pH}=7$

Fig. 10. Summary of uranine calibration curves in tested reservoir waters at constant $\mathrm{pH}=7$ 
Biorąc pod uwagę wpływ pH na widmo absorpcji badanych znaczników fluorescencyjnych, konieczna była korekta odczynu roztworów fluoresceiny i uraniny w badanych wodach do $\mathrm{pH}=7$, natomiast roztwory eozyny żółtawej i rodaminy $\mathrm{B}$ w badanym zakresie $\mathrm{pH}$ były stabilne. Na podstawie otrzymanych wyników wykreślono krzywe kalibracyjne fluoresceiny, eozyny żółtawej, rodaminy B i uraniny w badanych wodach (rys. 7-10).

Do opisu krzywych kalibracyjnych roztworów barwnych znaczników fluorescencyjnych zastosowano wielomian I stopnia $y=a x+b$, który wystarczająco dobrze odwzorowywał zależność absorbancji od stężenia analitu. Współczynniki regresji zawierały się w przedziale od 0,9927 do 0,9998. Wysokie wartości współczynników regresji analizowanych znaczników świadczą o dobrym dopasowaniu liniowym. Zestawienie krzywych kalibracyjnych i współczynników regresji znaczników fluorescencyjnych zamieszczono w tabeli 3.

W celu sprawdzenia spektrofotometrycznej metody oznaczania barwnych znaczników fluorescencyjnych w wodach - wykonano po 10 analiz dla roztworów fluoresceiny, eozyny żółtawej, rodaminy B i uraniny w badanych wodach o stężeniach $10 \mathrm{mg} / \mathrm{dm}^{3}$ i $1 \mathrm{mg} / \mathrm{dm}^{3}$. Przy oznaczaniu ilościowym znaczników brano pod uwagę uprzednio sporządzone krzywe kalibracyjne. Na podstawie uzyskanych wyników obliczono wartości odchylenia standardowego, względnego odchylenia standardowego oraz średniej wartości stężeń. Analizując otrzymane wyniki, można stwierdzić, że opracowana metoda spektrofotometryczna charakteryzuje się dużą powtarzalnością oznaczeń w badanych zakresach stężeń, czego dowodem jest fakt, że żaden z wyników nie odbiega o więcej niż trzykrotną wartość odchylenia standardowego. Obliczone wartości względnego odchylenia standardowego, które są miarą precyzji metody analitycznej, zawierają się w granicach od 0,594\% do 3,801\% w roztworach o stężeniu analitów wynoszącym $10 \mathrm{mg} / \mathrm{dm}^{3}$ oraz od $6,730 \%$ do $10,954 \%$ w roztworach o stężeniu badanych znaczników wynoszącym $1 \mathrm{mg} / \mathrm{dm}^{3}$. Zestawienie obliczonych parametrów walidacyjnych dla roztworów badanych znaczników przedstawiono w tabeli 4.

\section{Badanie trwałości barwnych znaczników fluorescencyjnych w silnie zasiarczonych wodach złożowych}

Badania trwałości barwnych znaczników fluorescencyjnych w silnie zasiarczonych wodach złożowych przeprowadzono na roztworach fluoresceiny, eozyny żółtawej, rodaminy B oraz uraniny o stężeniu $10 \mathrm{mg} / \mathrm{dm}^{3} \mathrm{w}$ wodzie destylowanej, wodzie złożowej A4 i silnie zasiarczonych wodach złożowych A5 i A6. $\mathrm{W}$ trakcie testu badane roztwory były umieszczone w szczelnie zamkniętych naczyniach o pojemności $25 \mathrm{dm}^{3}$ i pozbawione dostępu światła słonecznego. Co dwa dni pobierano próbki roztworów o objętości $20 \mathrm{~cm}^{3}$ w celu oznaczenia stężenia znacznika w roztworze. Przed przystąpieniem do analizy ilościowej kontrolowano $\mathrm{pH}$ każdej z pobranych próbek za pomocą pehametru Elmetron CP-01. W przypadku próbek roztworów fluoresceiny i uraniny konieczna okazała się korekta $\mathrm{pH}$ za pomocą 0,1-molowego roztworu $\mathrm{NaOH}$. W próbkach znaczników w wodach wysokozmineralizowanych dodatek $\mathrm{NaOH}$ powodował wytrącanie się osadu, który usuwano poprzez oczyszczanie na filtrze strzykawkowym o średnicy porów $0,25 \mu \mathrm{m}$. Zawartość znaczników w roztworach badano na spektrofotometrze DR 3900 firmy Hach Lange. Pomiar stężenia badanych znaczników w roztworach prowadzono przez 1 miesiąc. Wyniki testów odporności barwnych znaczników fluorescencyjnych w silnie zasiarczonych wodach złożowych przedstawiono na rysunkach 11-14.

Przeprowadzone badania odporności barwnych znaczników fluorescencyjnych wykazały, że badane substancje znacznikowe są stabilne w wodzie destylowanej i wodzie złożowej A4, natomiast w silnie zasiarczonych wodach złożowych

Tabela 3. Zestawienie krzywych kalibracyjnych oraz współczynników regresji badanych znaczników fluorescencyjnych w wodzie destylowanej, wodzie złożowej A4 i silnie zasiarczonych wodach złożowych A5 i A6

Table 3. Summary of calibration curves and regression coefficients of the tested fluorescent tracers in the distilled water, A4 reservoir water and highly sulfated A5 and A6 reservoir waters

\begin{tabular}{|l|l|l|l|l|}
\hline \multirow{2}{*}{ Składnik } & \multicolumn{4}{|c|}{ Równanie krzywej kalibracyjnej znaczników w wodach } \\
\cline { 2 - 5 } & woda destylowana & woda zlożowa A4 & woda złożowa A5 & \multicolumn{1}{c|}{ woda zlożowa A6 } \\
\hline \hline \multirow{2}{*}{ Fluoresceina } & $y=0,1689 x+0,0931$ & $y=0,1412 x+0,0475$ & $y=0,155 x+0,0852$ & $y=0,1336 x+0,0702$ \\
& $R^{2}=0,9927$ & $R^{2}=0,9999$ & $R^{2}=0,995$ & $R^{2}=0,9997$ \\
\hline \multirow{2}{*}{ Eozyna żółtawa } & $y=0,1 x+0,0663$ & $y=0,0657 x+0,085$ & $y=0,0902 x+0,0727$ & $y=0,0554 x+0,0923$ \\
& $R^{2}=0,9997$ & $R^{2}=0,9997$ & $R^{2}=0,9996$ & $R^{2}=0,9933$ \\
\hline \multirow{2}{*}{ Rodamina B } & $y=0,1638 x+0,1016$ & $y=0,1378 x+0,0377$ & $y=0,1555 x+0,0646$ & $y=0,1241 x+0,0198$ \\
& $R^{2}=0,9988$ & $R^{2}=0,9996$ & $R^{2}=0,999$ & $R^{2}=0,9997$ \\
\hline \multirow{2}{*}{ Uranina } & $y=0,0757 x+0,0388$ & $y=0,0686 x+0,0154$ & $y=0,0698 x+0,0326$ & $y=0,0606 x+0,0322$ \\
& $R^{2}=0,9985$ & $R^{2}=0,9999$ & $R^{2}=0,9975$ & $R^{2}=0,9998$ \\
\hline
\end{tabular}




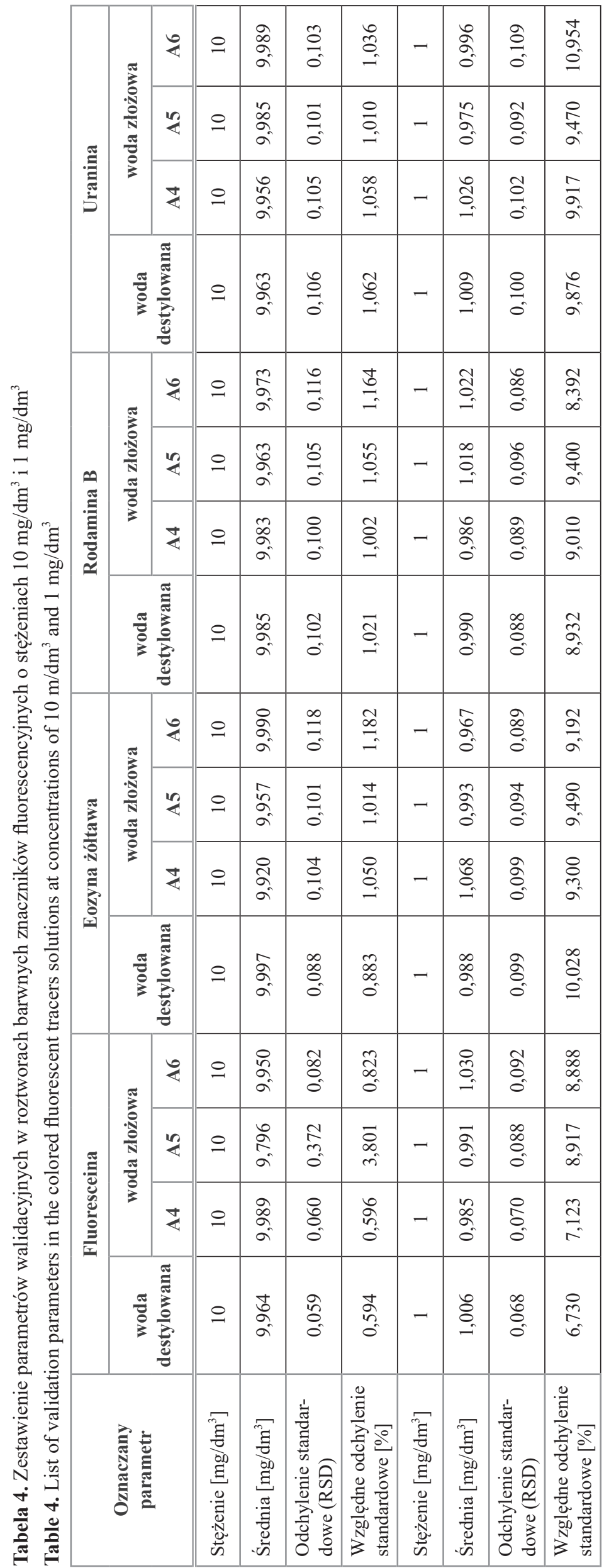

A5 i A6 ulegają degradacji. Najbardziej wrażliwe okazały się fluoresceina i jej pochodna uranina, które w wodzie złożowej A6 uległy całkowitej degradacji po 20 (fluoresceina) i 22 (uranina) dniach. Nieznacznie bardziej trwałe w silnie zasiarczonych wodach złożowych były eozyna żółtawa i rodamina B, które w wodzie złożowej A6 uległy całkowitej degradacji po 24 dniach. Ponadto na podstawie uzyskanych wyników badań stwierdzono, że degradacja barwnych znaczników fluorescencyjnych w silnie zasiarczonych wodach złożowych najbardziej intensywnie zachodzi w pierwszych dniach prowadzenia testu. Stopnie degradacji fluoresceiny, eozyny żółtawej, rodaminy i uraniny po tygodniu wynosiły odpowiednio: $48,08 \%$, $28,63 \%, 26,98 \%$ i $43,35 \%$ w wodzie złożowej A5 oraz $62,92 \%, 37,24 \%, 67,75 \%$ i 52,59\% w wodzie złożowej A6. Po dwóch tygodniach stopnie degradacji fluoresceiny wynosiły $80,65 \%$ (woda A5) i 96,47\% (woda A6), a uraniny $75,91 \%$ (woda A5) i 84,21\% (woda A6). Stężenie eozyny żółtawej po dwóch tygodniach testu zmalało z $10 \mathrm{mg} / \mathrm{dm}^{3}$ do 4,54 $\pm 0,45 \mathrm{mg} / \mathrm{dm}^{3}$ w wodzie złożowej A5 i do 3,93 \pm $0,39 \mathrm{mg} / \mathrm{dm}^{3}$ w wodzie złożowej A6. Rodamina B po 2 tygodniach uległa degradacji w $48,85 \%$ w wodzie złożowej A5 i w 88,70\% w wodzie złożowej A6. Po miesiącu prowadzenia procesu zawartość badanych znaczników fluorescencyjnych w roztworach spadła poniżej $0,1 \mathrm{mg} / \mathrm{dm}^{3}$. Wyjątek stanowiła eozyna żółtawa, której stężenie w wodzie złożowej A5 po miesiącu wynosiło $0,74 \pm 0,09 \mathrm{mg} / \mathrm{dm}^{3}$.

Biorąc pod uwagę wyniki testów stabilności fluoresceiny, eozyny żółtawej, rodaminy B i uraniny w silnie zasiarczonych wodach złożowych, stwierdzono, że barwne znaczniki fluorescencyjne nie są trwałe w wodach złożowych o wysokiej zawartości siarkowodoru. Porównując wyniki testów stabilności roztworów barwnych znaczników fluorescencyjnych w wodzie destylowanej i wysokozmineralizowanej wodzie złożowej A4 z roztworami tych znaczników w silnie zasiarczonych wodach złożowych A5 i A6, nasuwa się wniosek, że siarkowodór i inne związki siarki mogą mieć degradacyjny wpływ na roztwory fluoresceiny, eozyny żółtawej, rodaminy B oraz uraniny.

\section{Podsumowanie}

1. Terminem znaczniki (ang. tracers) określa się substancje chemiczne, które można łatwo oznaczać w celu badania procesów chemicznych, fizycznych lub biologicznych zachodzących w różnych układach. Substancje znacznikowe mogą pomóc w przedstawieniu charakterystyki badanego złoża, zobrazowaniu ścieżek przepływu płynów w złożu, ujawnieniu połączeń między 


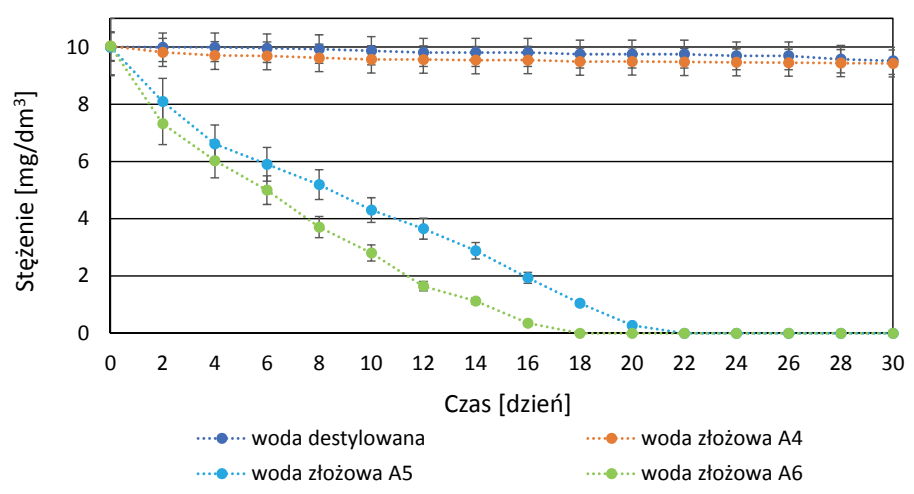

Rys. 11. Badania stabilności fluoresceiny w badanych roztworach

Fig. 11. Testing of the stability of fluorescein in tested solutions

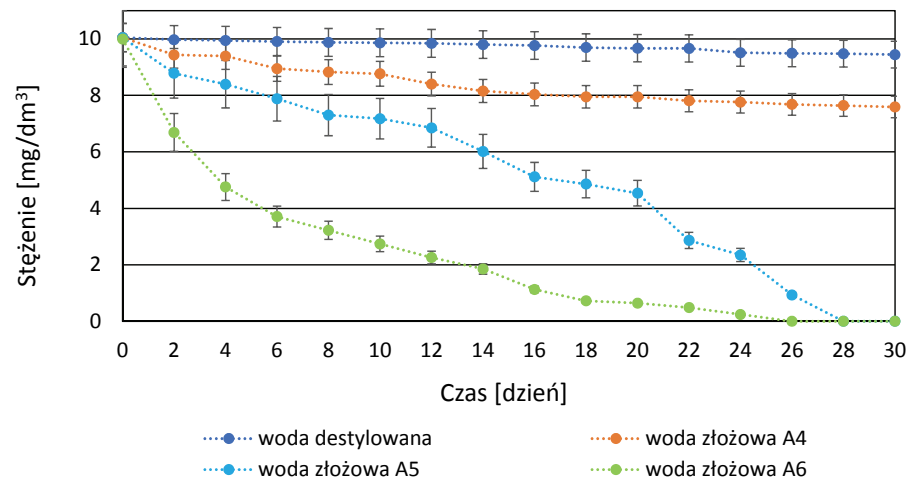

Rys. 13. Badania stabilności rodaminy $B \mathrm{w}$ badanych roztworach

Fig. 13. Testing of the stability of rhodamine B in tested solutions

odwiertami (planowanych oraz nieoczekiwanych), stwierdzeniu udziału ropy, gazu i wody w złożu, jak również określeniu pozostałego nasycenia złoża ropą.

2. Przeprowadzone badania wykazały, że barwne znaczniki fluorescencyjne są wrażliwe na zmianę $\mathrm{pH}$ roztworu, w związku z czym w badaniach należy stosować buforowane lub stabilizowane (poprzez dodatek substancji stabilizujących, np. EDTA) roztwory tych znaczników. Ponadto w przypadku wód złożowych należy sprawdzić odczyn roztworu przed analizą i w razie konieczności przeprowadzić jego korektę przez dodanie $\mathrm{HCl}$ lub $\mathrm{NaOH}$, co pozwoli na wyeliminowanie błędów jakościowych i ilościowych związanych ze zmianą $\mathrm{pH}$ wody złożowej w trakcie testu.

3. Opracowana metodyka oznaczania barwnych znaczników fluorescencyjnych w wodach z wykorzystaniem spektrofotometru DR 3900 firmy Hach Lange pozwala na oznaczenie badanych znaczników fluorescencyjnych w zakresie stężeń od $0,1 \mathrm{mg} / \mathrm{dm}^{3}$ do $10 \mathrm{mg} / \mathrm{dm}^{3}$.

4. Przeprowadzona walidacja metody analitycznej potwierdza wysoką dokładność i powtarzalność uzyskanych wyników.

5. Badania trwałości substancji znacznikowych wykazały, że fluoresceina, eozyna żółtawa, rodamina B i uranina ulegają degradacji w wodach silnie zasiarczonych. Po 30 dniach testu zawartość badanych znaczników fluorescencyjnych

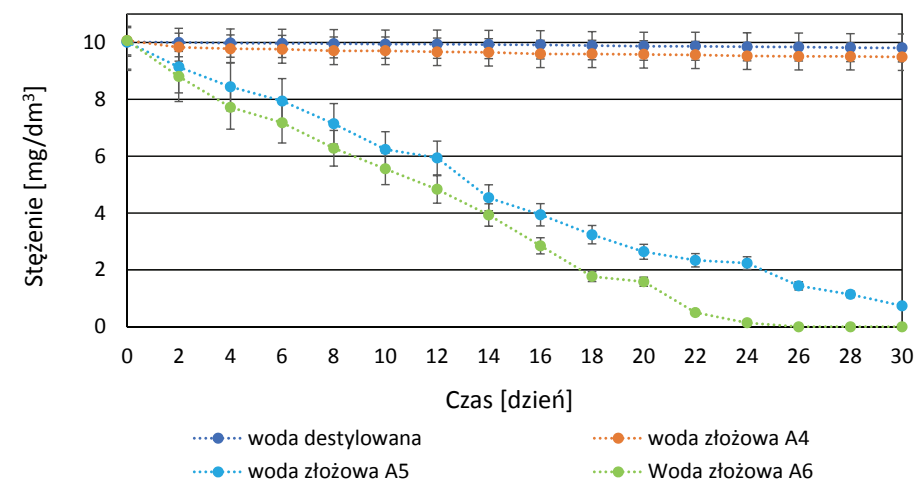

Rys. 12. Badania stabilności eozyny żółtawej w badanych roztworach Fig. 12. Testing of the stability of eosin yellowish in tested solutions

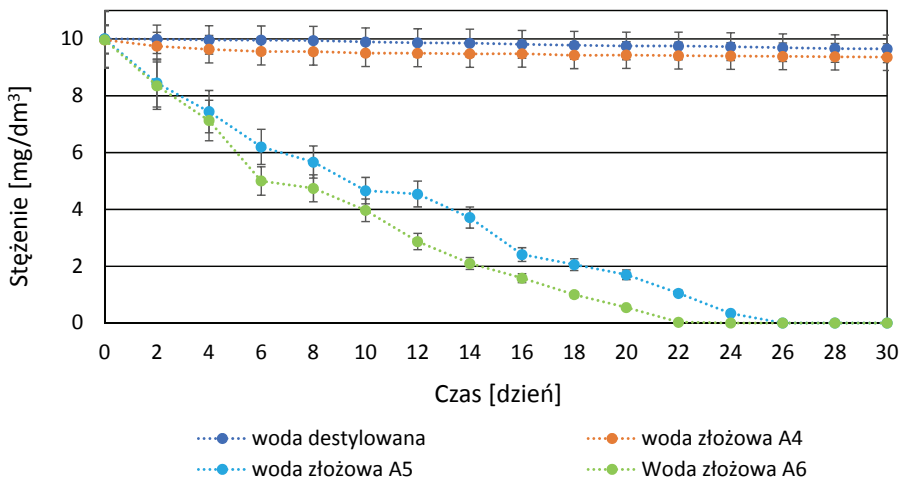

Rys. 14. Badania stabilności uraniny w badanych roztworach

Fig. 14. Testing of the stability of uranine in tested solutions

w wodzie złożowej A5 i A6 spadła poniżej granicy oznaczalności $\left(<0,1 \mathrm{mg} / \mathrm{dm}^{3}\right)$.

Artykuł powstał na podstawie pracy statutowej pt. Badania laboratoryjne możliwości stosowania substancji znacznikowych do monitorowania migracji wód w złożu - praca INiG - PIB na zlecenie MNiSW, nr zlecenia: 0066/KE/2020, nr archiwalny: DK-4100-0054/2020.

\section{Literatura}

Asadi M., Shook G.M., 2010. Application of Chemical Tracers in IOR: A Case History. Proceedings of the North Africa Technical Conference and Exhibition, Society of Petroleum Engineers, Cairo, Egypt.

Birtalan E., Rudat B., Kölmel D.K., Fritz D., Vollrath S.B., Schepers U., Bräse S., 2011. Investigating rhodamine B-labeled peptoids: scopes and limitations of its applications. Biopolymers, 96(5): 694-701. DOI: 10.1002/bip.21617.

Buzády A., Erostyák J., Paál G., 2006. Determination of uranine tracer dye from underground water of Mecsek Hill, Hungary. Journal of Biochemical and Biophysical Methods, 69(1-2): 207-214. DOI: 10.1016/j.jbbm.2006.05.009.

Cao V., Schaffer M., Taherdangkoo R., Licha T., 2020. Solute reactive tracers for hydrogeological applications: a short review and future prospects. Water, 12(653): 1-21. DOI: 10.3390/w12030653.

Chrysikopoulos C.V., 1993. Artificial tracers for geothermal reservoir studies. Environmental Geology, 22: 60-70. DOI: 10.1007/ BF00775286. 
Doughty M.J., 2010. pH dependent spectral properties of sodium fluorescein ophthalmic solutions revisited. Ophthalmic and Physiological Optics, 30(2): 167-174. DOI: 10.1111/j.1475-1313.2009.00703.x.

Doveri M., Mussi M., 2014. Water Isotopes as Environmental Tracers for Conceptual Understanding of Groundwater Flow: An Application for Fractured Aquifer Systems in the „ScansanoMagliano in Toscana" Area (Southern Tuscany, Italy). Water, 6: 2255-2277. DOI: 10.3390/w6082255.

Elliot T. (ed.), 2014. Environmental Tracers. MDPI. ISBN: 978-3-906980-92-8.

Gerke K.M., Sidle R.C., Mallants D., 2013. Criteria for selecting fluorescent dye tracers for soil hydrological applications using Uranine as an example. Journal of Hydrology and Hydromechanics, 61(4): 313-325. DOI: 10.2478/johh-2013-0040.

Guan L., Du Y., 2004. Will Tracer Move the Same Velocity as Its Carrier? SPE Annual Technical Conference and Exhibition, Houston, Texas.

Hardy R.A., Pates J.M., Quinton J.N., Coogan M.P., 2016. A novel fluorescent tracer for real-time tracing of clay transport over soil surfaces. CATENA, 141: 39-45. DOI: 10.1016/j.catena.2016.02.011.

Huseby O., Valestrand R., Nævdal G., Sagen J., 2010. Natural and Conventional Tracers for Improving Reservoir Models Using the EnKF Approach. SPE Journal, 15(4): 1047-1061. DOI: 10.2118/121190-PA.

Jang Y.H., Hwang S., Chung D.S., 2001. Tautomeric Equilibrium of Fluorescein in Solution: Ab Initio Calculations. Chemistry Letters, 30(12): 1316-1317. DOI: 10.1246/cl.2001.1316.

Jaworski T.J., 2005. Rozkład czasu przebywania materiału odpadów na ruszcie posuwistym i posuwisto-zwrotnym urządzeń do termicznego przekształcania odpadów. Archiwum Gospodarki Odpadami i Ochrony Środowiska, 2: 57-68.

Kania M., Matyasik I., 2013. Testy stabilności znaczników fluorescencyjnych wykorzystywanych do śledzenia kierunku migracji płynów w złożach gazu ziemnego. Nafta-Gaz, 4: 289-296.

Käss W., 1998. Tracing Technique in Geohydrology. Taylor \& Francis Group. ISBN: 9789054104445.

Mäntele W., Deniz E., 2017. UV-VIS absorption spectroscopy: Lambert-Beer reloaded. Spectrochimica Acta Part A: Molecular and Biomolecular Spectroscopy, 173: 965-968. DOI: 10.1016/j. saa.2016.09.037.

National Center for Biotechnology Information, 2020a. Eosin-Y. $<$ https://pubchem.ncbi.nlm.nih.gov/compound/Eosin-Y> (dostęp: 10.09.2020).

National Center for Biotechnology Information, 2020b. Fluorescein. $<$ https://pubchem.ncbi.nlm.nih.gov/compound/Fluorescein $>$ (dostęp: 30.08.2020).

National Center for Biotechnology Information, 2020c. Rhodamine-B. $<$ https://pubchem.ncbi.nlm.nih.gov/compound/Rhodamine-B $>$ (dostęp: 10.09.2020).

National Center for Biotechnology Information, 2020d. Uranine. $<$ https://pubchem.ncbi.nlm.nih.gov/compound/Uranine> (dostęp: 10.09.2020).

Naurath L., Weidner C., Rüde T.R., Banning A., 2011. A new approach to quantify Na-fluorescein (uranine) in acid mine waters.
Maine Water and the Environment, 30: 231-236. DOI: 10.1007/ s10230-011-0138-4.

Niazi A., Yazdanipour A., Ghasemi J., Amini A., Bozorgzad S., Kubista K., 2008. Spectrophotometric Investigation of the Acidity Constants of Fluorescein in Various Water-Organic Solvent Media. Chemical Engineering Communications, 195: 1257-1268. DOI: 10.1080/00986440801943677.

Nishikiori H., Tagami K., Matsunaga S., Teshima K., 2019. In Situ Probing of Photoinduced Hydrophilicity on Titania Surface Using Dye Molecules. ACS Omega, 4: 5944-5949. DOI: 10.1021/acsomega.9b00151.

Serres-Piole C., Preud'homme H., Moradi-Tehrani N., Allanic C., Jullia H., Lobinski R., 2012. Water tracers in oilfield applications: Guidelines. Journal of Petroleum Science and Engineering, 98-99: 22-39. DOI: 10.1016/j.petrol.2012.08.009.

Shook G.M., Pope G.A., Asakawa K. 2009. Determining Reservoir Properties and Flood Performance From Tracer Test Analysis. SPE Annual Technical Conference and Exhibition, Society of Petroleum Engineers, New Orleans, Louisiana.

Slyusareva E.A., Gerasimova M.A., 2014. pH-Dependence of the Absorption and Fluorescent Properties of Fluorone Dyes in Aqueous Solutions. Russian Physics Journal, 56: 1370-1377. DOI: $10.1007 / \mathrm{s} 11182-014-0188-8$.

Such J., 2010. Możliwości wykorzystania znaczników chemicznych w krajowym górnictwie nafty i gazu. Nafta-Gaz, 7: 621-629.

Wang P., Cheng M., Zhang Z., 2014. On different photodecomposition behaviors of rhodamine $\mathrm{B}$ on laponite and montmorillonite clay under visible light irradiation, Journal of Saudi Chemical Society, 18(4): 308-316. DOI: 10.1016/j.jscs.2013.11.006.

Weidner C., Naurath L., Rüde T.R., Banning A., 2011. Parameters affecting Na-fluorescein (uranine) detection in mine water tracer tests, Mine Water - Managing the Challenges. IMWA, Aachen, Germany: 85-89.

Yamashita H., Tanaka A., Nishimura M., Koyano K., Tatsumi T., Anpo M., 1998. Photochemical properties of Rhodamine-B dye molecules included within mesoporous molecular sieves. Studies in Surface Science and Catalysis, 117: 551-558. DOI: 10.1016/ S0167-2991(98)81037-9.

Yeh H.-F., Lin H.-I., Lee C.-H., Hsu K.-C., Wu C.-S., 2014. Identifying Seasonal Groundwater Recharge Using Environmental Stable Isotopes. Water, 6(10): 2849-2861. DOI: 10.3390/w6102849.

Zemel B., 1995. Tracers in the oil field. Elsevier, Amsterdam, New York. ISBN: 9781281034595.

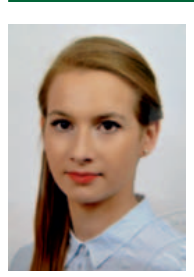

Mgr Katarzyna WOJTOWICZ

Asystent w Zakładzie Technologii Eksploatacji Płynów Złożowych

Instytut Nafty i Gazu - Państwowy Instytut Badawczy ul. Lubicz 25 A

31-503 Kraków

E-mail: katarzyna.wojtowicz@inig.pl 